\title{
Molecular typing and investigation of carbapenemases in carbapenem resistant Acinetobacter baumannii isolates
}

\section{Karbapenemlere dirençli Acinetobacter baumannii izolatlarında moleküler tiplendirme ve karbapenemazların araștırılması}

Nilgün ÖZBEY¹, Müșerref TATMAN-OTKUN²

\begin{abstract}
Objective: In this study, it was aimed to investigate the presence of carbapenemases in carbapenem-resistant $A$. baumannii strains and their chromosomal or plasmid origin.

Methods: Of the total $65 \mathrm{~A}$. baumannii studied, $66 \%$ were isolated from patients in intensive care unit (ICU); most of strains were blood (37\%) and lower respiratory tract samples (32\%). VITEK2 automated system and disk diffusion tests were used to evaluate antibiotic susceptibilities. In addition, MIC values for carbapenems were determined using M.I.C. evaluator strips. Clonal relationship between the isolates was assessed by AP-PCR, using M13 and DAF4 primers. Carbapenemase genes were screened by multiplex$\mathrm{PCR}$, and presence of plasmid-borne carbapenemase was investigated.

Results: The The isolates were found to be susceptible to tobramycin, netilmicin, and colistin by $98.5 \%, 98.5 \%$ and $96.9 \%$, respectively. The rates of resistance to other antibiotics were quite high, and resistance was found between $78.5 \%-100 \%$. The resistance rates were detected as $100 \%$ to ticarcillin, piperacillin, piperacillin+tazobactam, ceftazidime, ceftriaxone, sefepime, imipenem, meropenem, and
\end{abstract}

\section{ÖZET}

Amaç: Bu çalıșmada karbapenem dirençli $A$. baumannii'lerde karbapenemazların varlığı ve bunların kromozomal veya plazmid kaynaklı olduğunun araștırılması amaçlanmıștır.

Yöntemler: Çalıșılan 65 A. baumannii'nin \%66'sı yoğun bakım ünitesi (YBÜ)'ndeki hastalardan, en çok kandan (\%37) ve alt solunum yolu örneklerinden (\%32) izole edilmiștir. Antibiyotik duyarılıklarını değerlendirmede VITEK 2 otomatize sistemi ve disk difüzyon testi kullanılmıștır. Ayrıca, karbapenemler için MiK değerleri, MiK değerlendirici stripler kullanılarak belirlenmiștir. İzolatlar arasındaki klonal ilișki M13 ve DAF4 primerleri kullanılarak AP-PZR ile değerlendirilmiștir. Karbapenemaz genleri multipleksPZR ile taranmış ve plazmit kaynaklı karbapenemaz araștırılmıștır.

Bulgular: İzolatlar tobramisin, netilmisin ve kolistine sırasıly \%98.5, \%98.5 ve \%96.9 oranında duyarlı bulunmuștur. Diğer antibiyotiklere direnç oranları oldukça yüksek olup \%78.5-100.0 arasında saptanmıștır. Tikarsilin, piperasilin, piperasilin+tazobaktam, seftazidim, seftriakson, sefepim, imipenem, meropenem ve siprofloksasin için \%100.0; tikarsilin+klavulanik asit, gentamisin,

' Bitlis State Hospital, Medical Microbiology Laboratory, Bitlis, Turkey

${ }^{2}$ Çanakkale Onsekiz Mart University, School Of Medicine, Department Of Medical Microbiology, Çanakkale, Turkey

İletişim/ Corresponding Author : Müșerref TATMAN-OTKUN

Çanakkale Onsekiz Mart University, School Of Medicine, Department Of Medical Microbiology, Çanakkale

Turkey Tel : +905353551656 E-posta/E-mail : otkun2000@yahoo.com

Geliş Tarihi / Received : 09.11.2015 Kabul Tarihi / Accepted : 27.05 .2016

DOI ID : 10.5505/TurkHijyen.2016.91489

Özbey N, Tatman-Otkun M. Molecular typing and investigation of carbapenemases in carbapenem resistant Acinetobacter baumannii isolates. Turk Hij Den Biyol Derg, 2016; 73(4): 345-354 
ciprofloxacin, $98.5 \%$ to ticarcillin+clavulanic acid, gentamicin, levofloxacin, tetracycline, doxycycline, and trimethoprim-sulfamethoxazole, $93.8 \%$ to minocycline, $92.3 \%$ to amikacin, and $78.5 \%$ to ampicillin+sulbactam. In the study, two different patterns were observed by AP-PCR. Chromosomal OXA-23 and OXA-51 carbapenemase enzyme genes positively were found in all isolates. Plasmids were isolated neither of isolates.

Conclusion: Isolates were detected more frequently from hemocultures in ICU. Isolates showed clonal similarity in AP-PCR where M13 and DAF4 primers were used. The presence of the single Acinetobacter clone in our hospital suggests that they all originated from the same source. For this reason, it is concluded that universal infection control measures should be taken in consideration to prevent cross-infection by carbapenem resistant isolates.

Key Words: Acinetobacter baumannii, oxacillinase, metallo-beta-lactamase, PCR

\section{INTRODUCTION}

Acinetobacter baumannii is one of the important causes of nosocomial infections. It is widely present in nature, soil and water, and an opportunistic pathogen that can cause nosocomial cross-transmission between patients, leading to colonization or serious infections (1).

As a result of misuse of broad-spectrum antibiotics, multiresistant Acinetobacter species have emerged. The most frequently isolated and antibiotic-resistant species in nosocomial infections is $A$. baumannii (1). levofloksasin, tetrasiklin, doksisiklin ve trimethoprim+sulfametoksazol için \%98.5; minosiklin için \%93.8; amikasin için \%92.3 ve ampisilin+sulbaktam için \%78.5 oranında direnç saptanmıștır. AP-PZR ile araștırmada iki farklı patern gözlenmiștir. Bütün izolatlarda kromozomal kaynaklı OXA-23 ve OXA51 karbapenemaz enzim geni pozitif bulunmuștur. İzolatların hiçbirinde plazmit izole edilmemiștir.

Sonuç: İzolatlar en sık YBÜ'de yatmakta olan hastaların kan örneklerinde saptanmıștır. İzolatlar M13 ve DAF4 primerlerin kullanıldığı AP-PZR'de klonal benzerlik göstermiștir. Hastanemizde tek Acinetobacter kolonu bulunması, hepsinin aynı kaynaktan köken aldığını düşündürmektedir. Bu nedenle karbapeneme dirençli izolatların çapraz enfeksiyonlarını önlemek için evrensel enfeksiyon kontrol önlemlerine dikkat etmek gerektiği sonucuna varılmıștır.

Anahtar Kelimeler: Acinetobacter baumannii, oksasilinaz, metallo-beta-laktamaz, PZR. coccobacilli, they are immotile and do not have cytochrome oxidase activity. Currently there are at least 25 genomospecies described within the genus Acinetobacter. Because of problems in separating the saccharolytic strains belonging to DNA groups 1 , 2, 3 and 13 using phenotypic tests, some laboratories have chosen to report members of this group as "Acinetobacter calcoaceticus - A. baumannii complex", or saccharolytic Acinetobacter. A. baumannii acidifies most OF (oxidative-fermentative) 
carbohydrates; in particular, definitive identification is made by demonstrating the rapid production of acid from lactose or glucose. Furthermore $A$. baumannii can grow at $42^{\circ} \mathrm{C}$, but other Acinetobacter species cannot grow. (1).

Although Acinetobacter species are currently less sensitive to carbanepems, they are still among the most effective antibiotics. However, changes in penicillin-binding proteins, reduced outer membrane permeability, and production of chromosomal or plasmid-induced beta-lactamases (carbapenemases) cause resistance to carbanepems (2). The most prevalent mechanism of carbapenem resistance in $A$. baumannii is the production of carbapenemhydrolyzing B-lactamases, i.e., metallo-B-lactamases (ambler class B) and more usually oxacillinases (ambler class D). Carbapenem-hydrolyzing class D B-lactamases (CHDLs) are currently classified into six subgroups; acquired OXA-23-like, OXA-24/40-like, OXA-58-like, OXA-143-like and OXA-235-like, and the intrinsic OXA-51-like B-lactamases (3).

A. baumannii produces class $D$ oxacillinase that belongs to the chromosomal OXA-51-like enzyme group showing weak carbapenemase activity. However, OXA-51-like enzyme is secreted in high quantities in the presence of ISAba1 gene, causing high-level carbapenem resistance (4).

The metallo-beta-lactamases (MBL), the other carbapenemase group, are named because of the metal ions they carry in their active regions. The described MBL groups include IMP, VIM, SIM, and SPM. A. baumannii carries various IMP variants (IMP-1, IMP-2, IMP-4, IMP-5, IMP-6, IMP-8, and IMP-11), but rarely carries the other enzymes (5).

The purpose of this study was to assess the presence of carbapenemases of chromosomal and plasmid origin in carbapenem-resistant $A$. baumannii strains isolated in our hospital and also to investigate the clonal relationship between isolates.

\section{MATERIALS AND METHODS}

The study included carbapenem- and multipleresistant $A$. baumannii strains isolated in patients hospitalized in the School of Medicine Hospital between December 2009 and November 2011. In case of isolation of more than one strain of $A$. baumannii from the same patient, only one strain was included in the study if the antibiotic susceptibility patterns of all isolates were the same.

Strains isolated and identified as A. calcoaceticus- $A$. baumannii complex by a VITEK2 automated system (bioMérieux, France) were stored in liquid medium with beads (Pro-Lab, Canada) at $-80^{\circ} \mathrm{C}$ until the time of use. The stored strains and $A$. baumannii ATCC 19606 strain were subcultured twice on eosin-methylene blue agar (Salubris, Turkey) at $37^{\circ} \mathrm{C}$ for 24 hours. Strains were confirmed as $A$. baumannii, with acid producing from glucose in OF medium and growth ability at $42^{\circ} \mathrm{C}$.

Disk diffusion tests with standard antibiotic disks (Oxoid, United Kingdom) were used for susceptibility tests except for carbapenems and colistin, in addition to VITEK2 automated system. M.I.C. evaluator strips (Oxoid, United Kingdom) were used for carbapenem susceptibility. The susceptibility to antibiotics other than netilmicin was evaluated according to the CLSI criteria (6). The susceptibility to netilmicin was evaluated according to the EUCAST (European Committee on Antimicrobial Susceptibility Testing) criteria (7). Pseudomonas aeruginosa ATCC 27853 and E. coli ATCC 25922 served as the quality control strains (6).

The genomic DNA of $A$. baumannii isolates and $A$. baumannii ATCC 19606 strain was extracted by using GeneJET Genomic DNA Purification Kit (Fermentas, United Kingdom) according to the manufacturer's instructions.

In assessing the clonal relationship between the isolates, arbitrarily primed polymerase chain reaction (AP-PCR) was performed using the M13 and DAF4 
primers (8). The PCR mixture was prepared to have a final volume of $25 \mu \mathrm{l}$. The final mixture contained $1 \mathrm{X}$ buffer solution, 25 pM M13 primer (5'-GAGGGTGGCGGTTCT-3'), 1.5 mM MgCl2; $400 \mu \mathrm{M}$ from each dATP, dGTP, dCTP, and dTTP; $1 \mathrm{U}$ Taq DNA polymerase, and sterile bi-distilled water; and finally $2 \mu \mathrm{DNA}$ was added to this mixture. The same mixture was prepared using 25pM of DAF4 primer (5'-CGGCAGCGCC-3'). The amplification program for M13 primer in the thermal cycler (Eppendorf, Germany) was as follows: at $94^{\circ} \mathrm{C}$ for 2 minutes, 35 cycles at $94^{\circ} \mathrm{C}$ for 20 seconds, at $50^{\circ} \mathrm{C}$ for 1 minute, at $72^{\circ} \mathrm{C}$ for 20 seconds, and lastly at $72^{\circ} \mathrm{C}$ for 5 minutes. The amplification program for DAF4 primer was as follows: at $94^{\circ} \mathrm{C}$ for 2 minutes, 45 cycles at $94^{\circ} \mathrm{C}$ for 40 seconds, and at $45^{\circ} \mathrm{C}$ for 40 seconds, at $72^{\circ} \mathrm{C}$ for 40 seconds, and lastly at $72^{\circ} \mathrm{C}$ for 5 minutes. The obtained PCR product was analyzed with $1 \%$ agarose gel electrophoresis by applying $100 \mathrm{~V}$ for 45 minutes (Wealtec, USA), then studied under UV transilluminator and photographed. Different band patterns of the isolates were evaluated. To determine the size and quantity, 80-10.000 bp DNA ladder (Fermentas, United Kingdom) and $1 \mathrm{~kb}$ DNA ladder (Fermentas, United Kingdom) were used and $A$. baumannii ATCC 19606 was used as the positive control with sterile deionized water as the negative control.

To assess the presence of carbapenemase in the isolates, multiplex-PCR was carried with OXA-23, OXA-24, OXA-51 and OXA-58 as the first group and then with IMP, VIM, SIM and SPM as the second group, using the primer pairs shown in Table $1(9,10)$. The PCR mixture was prepared to have a final volume of $25 \mu \mathrm{l}$. The final mixture contained $1 \mathrm{X}$ buffer solution, $12.5 \mathrm{pM}$ from each primer, $1.5 \mathrm{mM} \mathrm{MgCl2;} 200$ $\mu M$ from each dATP, dGTP, dCTP, and dTTP; $1.5 \mathrm{U}$ Taq DNA polymerase, and sterile bi-distilled water. Lastly, $3 \mu \mathrm{l}$ DNA extract was added to the solution. The amplification program was as follows: at $94^{\circ} \mathrm{C}$ for 3 minutes, 35 cycles at $94^{\circ} \mathrm{C}$ for 45 seconds, at $57^{\circ} \mathrm{C}$ for 45 seconds, at $72^{\circ} \mathrm{C}$ for 1 minute, and lastly at 72 ${ }^{\circ} \mathrm{C}$ for 5 minutes. The obtained PCR product was ana-
Table 1. Antimicrobial resistance rates of $A$. baumanii isolates (NEU Hospital 2010-2014).

\begin{tabular}{|c|c|}
\hline OXA-23-likeF & 5'-GAT CGG ATT GGA GAA CCA GA-3' \\
\hline OXA-23-likeR & 5'-ATT TCT GAC CGC ATT TCC AT-3' \\
\hline OXA-24-likeF & 5'-GGT TAG TTG GCC CCC TTA AA-3' \\
\hline OXA-24-likeR & 5'-AGT TGA GCG AAA AGG GGA TT-3' \\
\hline OXA-51-likeF & 5'-TAA TGC TTT GAT CGG CCT TG-3' \\
\hline OXA-51-likeR & 5'-TGG ATT GCA CTT CAT CTT GG-3' \\
\hline OXA-58-likeF & 5'-AAG TAT TGG GGC TTG TGC TG-3' \\
\hline OXA-58-likeR & 5'-CCC CTC TGC GCT CTA CAT AC-3' \\
\hline IMP1-F & 5'-CTA CCG CAG CAG AGT CTT TGC-3' \\
\hline IMP1-R & 5'-GAA CAA CCA GTT TTG CCT TAC C-3' \\
\hline SPM-F & 5'-CCT ACA ATC TAA CGG CGA CC-3' \\
\hline SPM-R & 5'-TCG CCG TGC CAG GTA TAA C-3' \\
\hline VIM-F & 5'-TCT ACA TGA CCG CGT CTG TC-3' \\
\hline VIM-R & 5'-TGT GCT TTG ACA ACG TTC GC-3' \\
\hline SIM-F & 5'-GTA CAA GGG ATT CGG CAT CG-3' \\
\hline SIM-R & 5'-TGG CCT GTT CCC ATG TGA G-3' \\
\hline
\end{tabular}

lyzed in $1 \%$ agarose gel electrophoresis by applying $100 \mathrm{~V}$ for 45 minutes (Wealtec, USA), then visualized under UV lamp and photographed. The presence of genes was assessed in the bands formed $(10,11)$. To determine the size and quantity, 80-10.000 bp DNA ladder and $1 \mathrm{~kb}$ DNA ladder were used. $A$. baumannii ATCC 19606 was used as the positive control with sterile deionized water as the negative control. Upstream presence of ISAba1 was not studied.

In order to assess the presence of plasmid-borne carbapenemase, GeneJET Plasmid Miniprep Kit (Fermentas, United Kingdom) was used according to the manufacturer's instructions. To determine the plasmids, the obtained plasmid DNA was run in $1 \%$ agarose gel electrophoresis by applying $100 \mathrm{~V}$ for 45 
minutes (Wealtec, USA), then studied under UV lamp and photographed, using 80-10.000 bp DNA ladder. As positive control $E$. coli strains isolated from patients were used with sterile deionized water as negative control.

\section{RESULTS}

The 65 clinical isolates of $A$. baumannii were isolated from 62 patients ( 33 male and 29 female). Different isolates were obtained from blood and respiratory secretion of one patient and from two cerebro-spinal fluid (CSF) specimens and blood of another patient. The age of the patients ranged from 4 to 91 with a mean age of $60.26 \pm 18.20$ years. Most of the isolates $(43 / 65,66.2 \%)$ were from the ICU, followed by other units ranging from 1.5 to $7.7 \%$. The isolates were, in order of frequency, blood (24/65, $36.9 \%)$, endotracheal aspirate $(16 / 65,24.6 \%)$, wound $(8 / 65,12.3 \%)$, urine $(8 / 65,12.3 \%)$, sputum $(5 / 65$, $7.7 \%), \operatorname{CSF}(2 / 65,3.1 \%)$, and tissue $(2 / 65,3.1 \%)$ isolates.

The antibiotic susceptibility results of disk diffusion and VITEK2 automated system were identical. The isolates were most susceptible to tobramycin and netilmicin for $98.5 \%$ and to colistin for $96.9 \%$. The isolates were highly resistant to other antibiotics tested. All of the isolates were found resistant to ticarcillin, piperacillin, piperacillintazobactam, ceftazidime, ceftriaxone, sefepime, imipenem, meropenem, and ciprofloxacin. Resistance rates to ticarcillin-clavulanic acid, gentamicin, levofloxacin, tetracycline, doxycycline, and trimethoprim-sulfamethoxazole were same and 98.5\%. Resistance rates to minocycline, amikacin and to ampicillin-sulbactam were $93.8 \%, 92.3 \%$ and $78.5 \%$ respectively.

All isolates belonged to same clone except the 33rd isolate with M13 and DAF4 primers in AP-PCR test (Figures 1 and 2). The 33rd isolate was from a wound in a patient who had an operation for lumbar disc hernia in another city two months prior to its isolation. This isolate was found to differ from other isolates by being susceptible to tetracycline, doxycycline, and minocycline; intermediately susceptible to levofloxacin, and resistant to tobramycin.

Three isolates from the same patient with different antibiotic susceptibility patterns were included in the study. This patient is a case who was hospitalized in the ICU with diagnosis of subarachnoid hemorrhage on December 3, 2010, was monitored by the Neurosurgery Clinic, and from whom $A$. baumannii had been isolated in the hemoculture on December 20, 2010 (35th isolate). This 35th isolate was the first isolate from this patient and its antibiotic susceptibility pattern was similar to those of other isolates from other patients and showed susceptibility to colistin. However, two isolates obtained from the CSF of the same patient on dates January 25 and February 17, 2011 (37th and 65th isolates, respectively) were found to be colistinresistant. The AP-PCR study showed that all these three isolates were not different from other isolates.

According to the results of multiplex-PCR test to assess the presence of oxacillinase and $M B L$, all isolates had OXA-23 of size 501 bp and OXA-51 of size 353 bp (Figure 3), but no genes of OXA-24, OXA-58, IMP-1, SPM, VIM, and SIM were found.

In assessing plasmid-borne carbapenemases, no plasmids was obtained from the isolates.

\section{DISCUSSION}

Nosocomial infections (NIs), causing long hospitalization, increased morbidity and mortality, and economic loss due to extra treatment expenditures, are important. Acinetobacter species are increasingly isolated as agents of Nls, particularly of those in ICUs. However, the differentiation of Acinetobacter spp. needs molecular confirmation techniques (12). The presence of blaOXA-51 gene also continues to be an appropriate genetic marker for $A$. baumannii identification (13). 


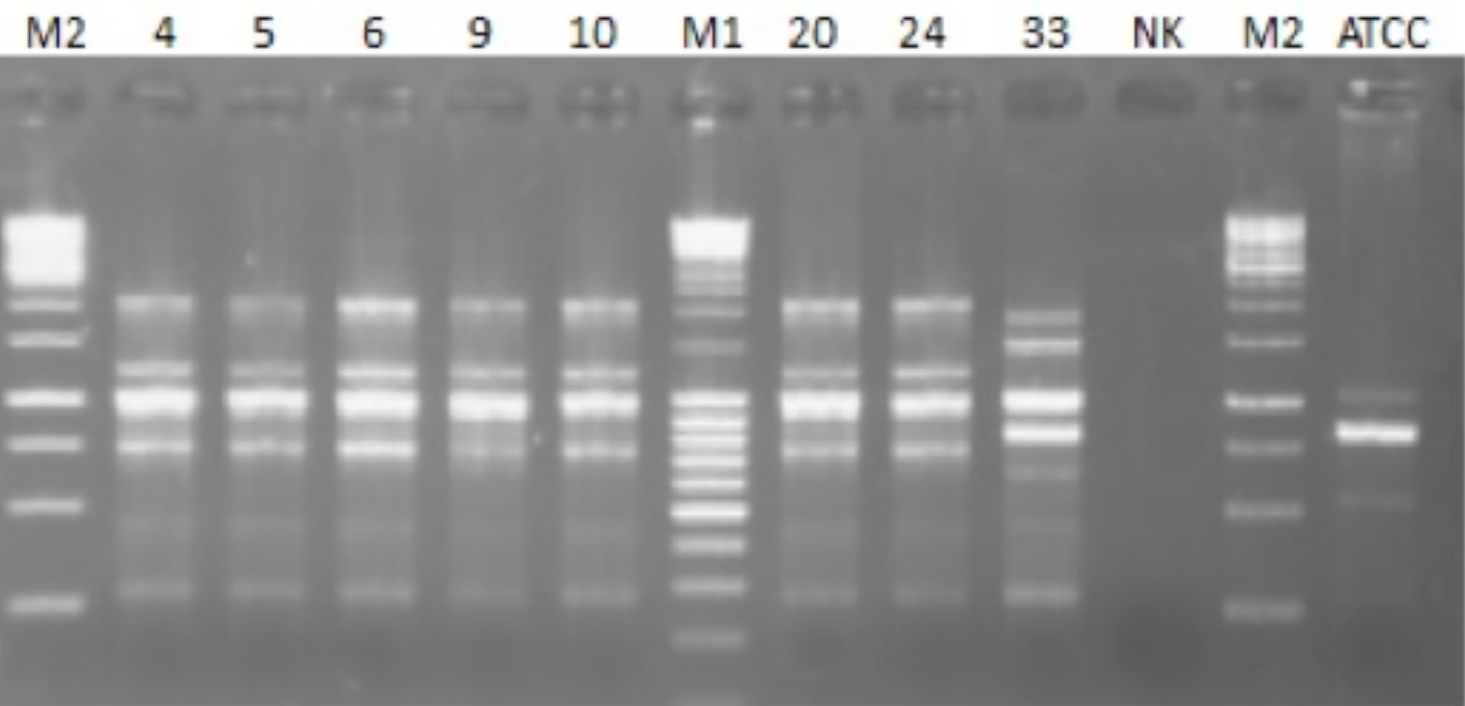

Figure 1. Different patterns by M13 primer. M1: 80-10.000 bp DNA ladder, M2: 1 kb DNA ladder, NK: Negative control, ATCC: A. baumannii 19606

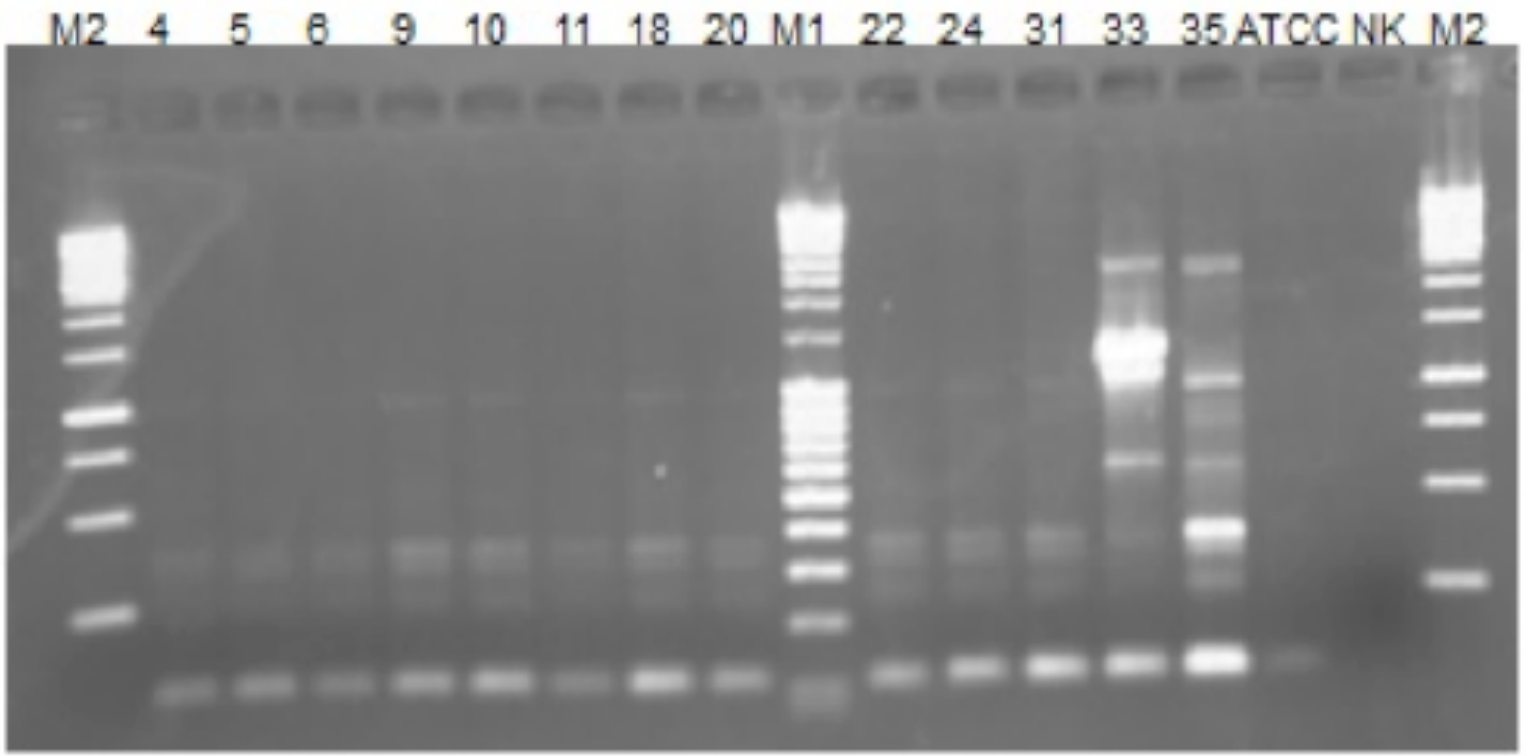

Figure 2. Different patterns by DAF4 primer. M1: 80-10.000 bp DNA ladder, M2: 1 kb DNA ladder, NK: Negative control, ATCC: A.baumannii 19606 


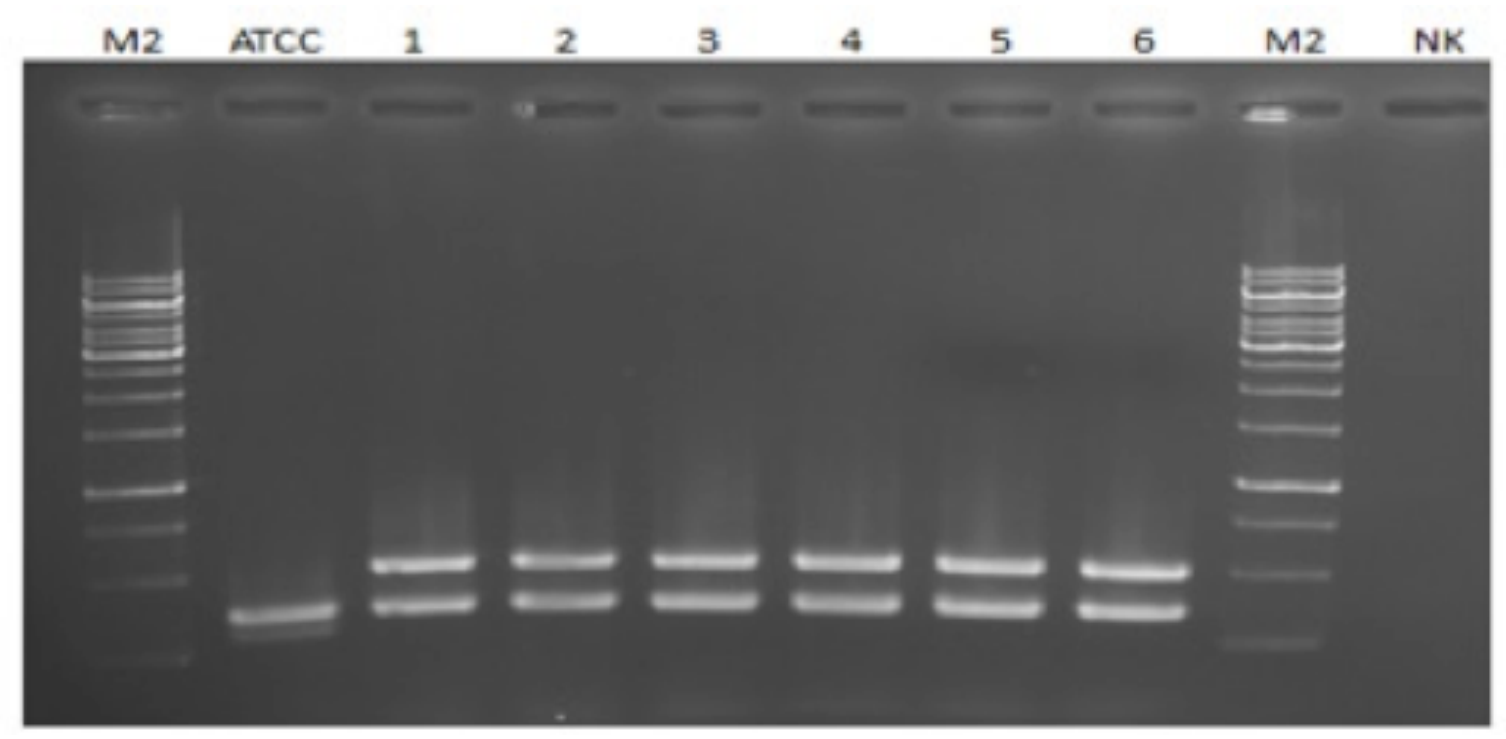

Figure 3. Multiplex PCR results. M2: 1 kb DNA ladder, NK: Negative control, ATCC: A. baumannii 19606

However, blaOXA-51 gene was also found recently in carbapenem-resistant non-baumannii species of Acinetobacter: A. nosocomialis (formerly Acinetobacter genomic species 13TU) and Acinetobacter genomic species "Close to 13U" (14). Members of the A. calcoaceticus - A. baumannii complex are A. calcoaceticus, $A$. baumannii, genomic species 3 and genomic species 13TU, so we accepted our isolates as A. calcoaceticus - $A$. baumannii complex. A. baumannii is the most frequently isolated agent among other species (12). It causes NIs such as pneumonia, sepsis, meningitis, and urinary infections in hospitalized patients, particularly among those treated in ICUs (15). Also in our study, we isolated A. baumannii most frequently from blood samples of patients in the ICU. The second most frequent body site for isolation was lower respiratory tract from which endotracheal aspirates and sputum were obtained.

Acinetobacter species are increasingly becoming multiple-antibiotic resistant, leading to difficulty in the treatment of infections they cause. Currently, NIs due to carbapenem-resistant $A$. baumannii strains are increasing. According to the results of the MYSTIC (Meropenem Yearly Susceptibility Test Information Collection) Antimicrobial Surveillance Program studies carried out by Hacettepe University, the most effective antibiotics against $A$. baumannii were meropenem by $53 \%$, imipenem by $48 \%$, and tobramycin by $44 \%$ (16). Iraz et al. in their study reported that their Acinetobacter isolates were susceptible to colistin and netilmicin at rates of $99 \%$ and $85 \%$, respectively (17). In our study, we found that $A$. baumannii isolates were most susceptible to tobramycin, netilmicin and colistin, whereas they showed minimal susceptibility to other antibiotics which cannot be considered for therapy. Generally, many carbapenem resistant A. baumannii clinical isolates were found to be resistant to aminoglycosides in many studies. We did not study the mechanisms for aminoglycoside resistance. Different resistance genes located on plasmids, transposons or class I integrons may be responsible for this resistance (18). It is possible to find different resistance profiles in different locations; for example in a study from Australia the carbapenem resistant isolates have OXA-23 genes, however resistance to 
netilmicin has not been found (19). The majority of our isolates belonged to a single clone, so the unusual aminoglycoside resistance profile (high resistance to amikacin compared to high susceptibility to netilmicin and tobramycin) may be associated with this matter.

The antibiotic resistance of Acinetobacter species has led investigators to seek other treatment alternatives. Infections caused by such resistant strains can be treated with colistin (20). In the last few years, infections caused by colistin-susceptible Acinetobacter have emerged and have been successfully treated with colistin. In our study, colistin was found to be the fourth most effective antibiotic against $A$. baumannii. In our hospital, colistin is used in the therapy of multipleresistant $A$. baumannii infections since susceptibility to netilmicin cannot be assessed by VITEK2 automated system AST-N90 card and since providing tobramycin as a drug is difficult. However, colistin has some serious side-effects which render its use problematic. Also, colistin-resistant and heteroresistant strains which are difficult to determine have emerged in recent years, limiting the use of colistin in therapy (21). In our study, we found two isolates of $A$. baumannii were resistant to colistin, namely, isolates numbered (no.) 37 and 65, belonging to the same patient. Isolate no. 37 was the first isolate obtained a month prior to isolate no. 65 . Following the isolation of colistin-resistant isolate no. 37 , the patient had received colistin therapy which might have led the present hetero-colistin-resistance to develop into colistin-resistance.

Since it is not possible to identify Acinetobacter species with phenotypic methods, genotypic methods are required for identification (22). PCR-based methods are widely used for the epidemiologic typing of $A$. baumannii. When PCR-based typing is compared with other methods, it enables differentiation similar to that of ribotyping, but less than that of PFGE. Concordance between PFGE, rep-PCR and MLST for $A$. baumannii typing has been shown in various studies (23). In a multi-center study with participation of different countries, Grundmann et al. reported that $P C R s$ carried out with isolated $A$. calcoaceticus- $A$. baumannii complex using M13, DAF4, ERIC2, and REP primer sets gave high rates of similar results. The authors also reported that similar results were obtained when standard DNA extraction and amplification conditions were provided and that with M13 primer more marked band patterns and thus better differentiation were obtained when compared with other primers (8).

In our study, we used the M13 and DAF4 primers, and with each primer we obtained two different bands, more marked with M13 primer. Isolate no. 33 was accepted as an exogenous isolate since it was obtained from a patient who had undergone an operation in another medical center one month prior to its isolation and showed antibiogram patterns different from those of other isolates. The same patterns were shared by all 65 isolates included in this study except isolate no. 33 which indicates that there is one single Acinetobacter clone from the same source in our hospital. Since $A$. baumannii strains are occasionally isolated in our hospital since 2009, it would be more correct to describe this clonal strain as an endemic strain rather than an epidemic strain. It is suggested that more attention should be given to universal infection control measures to prevent the transmission of bacteria between patients. Studying environmental samples routinely is not recommended. However, during epidemics environmental sampling should definitely be completed to determine the source of the causative microorganism and to obtain more relevant data (24).

The resistance to carbanepems is frequently associated with acquirement of genes responsible for the synthesis of carbapenamases which include oxacillinase and MBLs. Besides these genes, resistance to carbapenems is also caused by excess production of OXA-51 type natural oxacillinase (5). Gür et al. (25) in their study found OXA-58 in 18 (40.9\%) and OXA-23 in 26 (59.1\%) isolates. A multicenter study in Turkey reported the presence of OXA-51 in 100\%, OXA-23 in $74.4 \%$, and OXA-58 in $17.3 \%$ of carbapenem-resistant A. baumannii isolates, but absence of OXA-24 in all isolates (26). Another study reported the presence of OXA-51 in $100 \%$ and OXA-23 in $78.2 \%$ of carbapenemresistant $A$. baumannii isolates, but absence of OXA58 in all isolates (27). A study in Greece found OXA-51 in 15 and OXA-58 in 14 of the $17 \mathrm{~A}$. baumannii isolates, but no OXA-23 and OXA-24 (28). In the same study, the 
enzymes IMP, VIM, SIM, and SPM were investigated by using Etest and molecular methods, but MBL enzymes were not found with either method (28). A study in Brazil reported the presence of OXA-23 in all of $172 \mathrm{~A}$. baumannii isolates investigated, but absence of IMP, VIM, SIM, and SPM as MBL enzymes (10).

In our study, we investigated the presence of oxacillinase enzymes, namely, OXA-23, OXA-24, OXA51 , and OXA-58, and presence of MBL enzymes, namely, IMP, VIM, SIM, and SPM using multiplex-PCR. Since OXA23 and OXA-51 were present and OXA-24, OXA-58, IMP, VIM, SIM, and SPM were absent in all isolates, we consider that carbapenemase resistance could be due to excess production of OXA-type natural oxacillinase and to OXA-23 enzyme gene. We did not study the existence of ISAba1 genes, though it is reported that this gene provides the promoter for blaOXA51-like and blaOXA-23-like genes upstream of these carbapenemases and the resistance to carbapenems is closely related to the ISAba1 promoter (4).

Antibiotics used in the therapy of nosocomial A. baumannii are limited in number and in the near future emerging multiple-antibiotic resistant $A$. baumannii strains may cause infections that cannot be effectively treated. In view of these facts, to prevent cross-transmission of $A$. baumannii among patients colonized or infected, contact isolation should be carefully performed, medical staff should be regularly and repeatedly trained, importance of hand washing should always be stressed, and disinfection of the surroundings should be more frequently repeated.

\section{ACKNOWLEDGEMENTS}

This investigation was supported by the Scientific Research Projects of University (Project No: 2011/114).

\section{REFERENCES}

1. Winn WC, Allen SD, Janda WM, Koneman EW, Procop GW, Schreckenberger PC, Woods GL. The Nonfermentative Gram-Negative Bacilli. In: Winn WC, Allen SD, Janda WM, Koneman EW, Procop GW, Schreckenberger PC, Woods GL eds. Koneman's Color Atlas and Textbook of Diagnostic Microbiology. 6th ed. Philadelphia: Lippincott Williams-Wilkins, 2006: 303-391.

2. Lolans K, Rice TW, Munoz-Price S L, Quinn JP. Multicity outbreak of carbapenem- resistant Acinetobacter baumannii isolates producing the carbapenemase OXA-40. Antimicrob Agents Chemother, 2006; 50 (9): 2941-5.

3. Higgins PG, Perez-Llarena FJ, Zander E, Fernandez A, Bou G, Seifert H. OXA-235, a novel class D $B$-lactamase involved in resistance to carbapenems in Acinetobacter baumannii. Antimicrob Agents Chemother, 2013; 57(5): 2121-6.
4. Turton JF, Ward ME, Wood N, Kaufmann MEE, Pike R, Livermore DM, et al. The role of ISAba1 in expression of OXA carbapenemase genes in Acinetobacter baumannii. FEMS Microbiol Lett, 2006; 258: 72-7.

5. Poriel L, Nordmann P. Carbapenem resistance in Acinetobacter baumannii: Mechanisms and epidemiology. Clin Microbiol Infect, 2006; 12: 82636.

6. Clinical And Laboratory Standarts Institute. Performance standards for antimicrobial susceptibility testing: Twenty-Second Informational Supplement. CLSI document M100-S22. Clinical and Laboratory Standards Institute, USA. 2012.

7. European Committe On Antimicrobial Susceptibility Testing (EUCAST). Breakpoint tables for interpretation of MICs and zone diameters. v2.0. 2012. 
8. Grundmann HJ, Towner KJ, Dijkshoorn L, GernerSmidt $P$, Maher $M$, Seifert $H$, et al. Multicenter study using standardized protocols and reagents for evaluation of reproducibility of PCR-based fingerprinting of Acinetobacter spp. J Clin Microbiol, 1997; 35: 3071-7.

9. Woodford N, Ellington MJ, Coelho JM, Turton JF, Ward ME, Brown S, et al. Multiplex PCR for genes encoding prevalent OXA carbapenemases in Acinetobacter spp. Int J Antimicrob Agents, 2006; 27 (4): 351-3.

10. Bier KES, Luiz SO, Scheffer MC, Gales AC, Paganini MC, Nascimento AJ, et al. Temporal evolution of carbapenem resistant Acinetobacter baumannii in Curitiba, southern Brazil. American J Infect Control, 2010; 38: 308-14.

11. Turton JF, Gabriel SN, Valderrey C, Kaufmann ME, Pitt TL. Use of sequence-based typing and multiplex PCR to identify clonal lineages of outbreak strains of Acinetobacter baumannii. Clin Microbiol Infect, 2007; 13: 807-15.

12. Higgins PG, Lehmann $M$, Wisplinghoff $H$, Seifert $H$. gryB multiplex PCR to differentiate between Acinetobacter calcoaceticus and Acinetobacter genomic species 3. J Clin Microbiol, 2010; 48 (12): 4592-4.

13. Wang J, Ruan Z, Feng $Y$, Fu $Y$, Jiang $Y$, Wang $H$, et al. Species distribution of clinical Acinetobacter isolates revealed by different identification techniques. Journal Plos One, 2014 Aug 14; 9(8): e104882. DOI; 10.1371/journal.pone.0104882.

14. Nowak P, Paluchowska P, Budak A. Co-occurrence of carbapenem and aminoglycoside resistance genes among multidrug-resistant clinical isolates of Acinetobacter baumannii from Cracow, Poland. Med Sci Monit Basic Res, 2014; 20: 9-14.

15. Schreckenberger PC, Daneshvar MI, Hollis DG. Acinetobacter, Achromobacter, Chryseobacterium, Moraxella, and other nonfermantative Gramnegative rods. In: Murray PR, Baron EJ, Pfaller MA, Jorgensen JH, Landry M.L, eds. Manual of Clinical Microbiology. 9th ed. Washington DC: ASM Press, 2007; 770-802.

16. Zarakolu P, Hasçelik G, Ünal S. Antimicrobial susceptibility pattern of nosocomial Gram negative pathogens: Results from MYSTIC study in Hacettepe University adult Hospital (2000-2004). Mikrobiyol Bul, 2006; 40: 147-54.

17. Iraz M, Ceylan A, Akkoyunlu Y. Çeșitli klinik örneklerden izole edilen Acinetobacter türlerinde antibiyotik direnç oranlarının incelenmesi. ANKEM Dergisi, 2012; 26(2): 80-5.
18. Gordon NC, Wareham DW. Multidrug-resistant Acinetobacter baumannii; mechanism of virulence and resistance. Int J Antimicrob Agents, 2010; 35: 219-26.

19. Nigro SJ, Post V, Hall RM. Aminoglycoside resistance in multiply antibiotic-resistant Acinetobacter baumannii belonging to global clone 2 from Australian hospitals. J Antimirob Chemother, 2011; DOi; $10.1093 /$ jac/dkr163.

20. Levin AS, Barone AA, Penco J, Santos MV, Marinho IS, Arruda EAG, et al. Intravenous colistin therapy for nosocomial infections caused by multidrug-resistant Pseudomonas aeruginosa and Acinetobacter baumannii. Clin Infect Dis, 1999; 28: 1008-11.

21. Hawley JS, Murray CK, Jorgensen JH. Colistin heteroresistance in Acinetobacter and its association with previous colistin therapy. Antimicrob Agents Chemother, 2008; 52 (1): 351-2.

22. Olive DM, Principles PB. Principles and applications of methods for DNA-based typing of microbial organisms. J Clin Microbiol, 1999; 37(6): 1661-9.

23. Schuetz AN, Huard RC, Eshoo MW, Massire C, Della-Latta P, Wu F, et al. Identification of a novel Acinetobacter baumannii clone in a US hospital outbreak by multilocus polymerase chain reaction/ electrospray-ionization mass spectrometry. Diagnostic Microbiol Infect Dis, 2012; 72: 14-9.

24. Aygün G. Yoğun bakım birimi infeksiyonlarında çevre şartlarının önemi. Klimik Dergisi, 2003; 16(3): 106 7.

25. Gür D, Korten V, Ünal S, Deshpande LM, Castanheira $M$. Increasing carbapenem resistance due to the clonal dissemination of oxacillinase (OXA-23 and OXA-58)-producing Acinetobacter baumannii: Report from the Turkish SENTRY program sites. J Med Microbiol, 2008; 57: 1529-32.

26. Çiftçi iH, Așık G, Karakeçe E, Öksüz L, Yağcı $S$, Sesli-Çetin E, ve ark. Acinetobacter baumannii izolatlarında blaOXA genlerinin dağılımı: Çok merkezli bir çalıșma. Mikrobiyol Bul, 2013; 47(4): 592-602.

27. Çiçek AC, Saral A, Iraz $M$, Ceylan A, Düzgün AO, Peleg AY, et al. OXA- and GES-type b-lactamases predominate in extensively drug-resistant Acinetobacter baumannii isolates from a Turkish University Hospital. Clin Microbiol Infect, 2014; 20(5): 410-5.

28. Pournaras S, Markogiannakis A, Ikonomidis A, Kondyli L, Bethimouti K, Maniatis AN, et al. Outbreak of multiple clones of imipenem-resistant Acinetobacter baumannii isolates expressing OXA58 carbapenemase in an intensive care unit. J Antimicrob Chemother, 2006; 57: 557-61. 